\title{
Lanthanum triflate catalyzed rapid oxidation of secondary alcohols using hydrogen peroxide urea adduct (UHP) in ionic liquid
}

\author{
Pooja Saluja, Devanshi Magoo, Jitender M. Khurana*
}

Department of Chemistry, University of Delhi, Delhi-110007, India

Tel.: 9111 27667725-1384; Fax: 9111 27666605;

Email: jmkhurana1@yahoo.co.in

\section{SUPPORTING INFORMATION}

\section{General procedure for the oxidation of 1,2-diols (1a-i) to 1,2-diketones (2a-i).}

A mixture of 1,2-diol (1) (1.0 mmol), UHP (2.0 mmol), $10 \mathrm{~mol} \%\left(\mathrm{CF}_{3} \mathrm{SO}_{3}\right)_{3} \mathrm{La}$ and $[\mathrm{bmim}] \mathrm{BF}_{4}$ (5 mmol) was placed in a $50 \mathrm{~mL}$ RB flask fitted with a calcium chloride guard tube. The reaction mixture was stirred magnetically in an oil-bath maintained at $70^{\circ} \mathrm{C}$ for an appropriate time as mentioned in Table 2. The progress of the reaction was monitored by TLC using petroleum ether:ethyl acetate (70:30). After completion of the reaction, the reaction mixture was cooled to room temperature and washed with diethyl ether $(3 \times 10 \mathrm{~mL})$. The combined ethereal layer was washed with water $(2 \times 10 \mathrm{~mL})$ and dried over anhyd. $\mathrm{Na}_{2} \mathrm{SO}_{4}$. The ethereal extract was concentrated on a rotary evaporator to give corresponding 1,2-diketone.

\section{General procedure for the oxidation of $\alpha$-hydroxyketones (3a-f) to 1,2-diketones (2a-f).}

A mixture of $\alpha$-hydroxyketone (3) $(1.0 \mathrm{mmol})$, UHP $(2.0 \mathrm{mmol}), 10 \mathrm{~mol} \%\left(\mathrm{CF}_{3} \mathrm{SO}_{3}\right)_{3} \mathrm{La}$ and [bmim] $\mathrm{BF}_{4}(5 \mathrm{mmol})$ was placed in a $50 \mathrm{~mL} \mathrm{RB}$ flask fitted with a calcium chloride guard tube. The reaction mixture was stirred magnetically in an oil-bath maintained at $70^{\circ} \mathrm{C}$ for an 
appropriate time as mentioned in Table 2. The progress of the reaction was monitored by TLC using petroleum ether:ethyl acetate (70:30). After completion of the reaction, the reaction mixture was cooled to room temperature and washed with diethyl ether $(3 \times 10 \mathrm{~mL})$. The combined ethereal layer was washed with water $(2 \times 10 \mathrm{~mL})$ and dried over anhyd. $\mathrm{Na}_{2} \mathrm{SO}_{4}$. The ethereal extract was concentrated on a rotary evaporator to give corresponding 1,2-diketone.

General procedure for the oxidation of aliphatic or aromatic secondary alcohols (4a-l) to ketones (5a-1).

A mixture of secondary alcohol (4) (1.0 mmol), UHP (2.0-3.0 mmol), $10 \mathrm{~mol} \%\left(\mathrm{CF}_{3} \mathrm{SO}_{3}\right)_{3} \mathrm{La}$ and [bmim] $\mathrm{BF}_{4}(5 \mathrm{mmol})$ was placed in a $50 \mathrm{~mL} \mathrm{RB}$ flask fitted with a calcium chloride guard tube. The reaction mixture was stirred magnetically in an oil-bath maintained at $70^{\circ} \mathrm{C}$ for an appropriate time as mentioned in Table 2 . The progress of the reaction was monitored by TLC using petroleum ether:ethyl acetate (70:30). After completion of the reaction, the reaction mixture was cooled to room temperature and washed with diethyl ether $(3 \times 10 \mathrm{~mL})$. The combined ethereal layer was washed with water $(2 \times 10 \mathrm{~mL})$ and dried over anhyd. $\mathrm{Na}_{2} \mathrm{SO}_{4}$. The ethereal extract was concentrated on a rotary evaporator to give corresponding ketone. 
